\title{
Pengetahuan dan Perilaku Safety Riding Siswa SMA
}

\author{
Indri Wahyuningsih*, Syahra Ramdana
}

Fakultas IImu Kesehatan Universitas Muhammadiyah Malang

*Email: indri@umm.ac.id

\section{Abstract \\ Knowledge and Safety Riding Behavior Among High School Students}

Background: Young people are the most involved in traffic accidents in Indonesia, because of the risky driving style. High school students belong to one of the young age groups with an average age of 15-18 years. To ensure traffic safety, a safety riding program was established which includes disciplinary behavior in driving rules and procedures. Own behavior is influenced by factors, one of which is knowledge. Knowledge as a stimulus or stimulus and becomes the basis for action.

Purpose: To find the relationship between knowledge and safety riding behavior among high school students.

Method: This study used an analytical observational method with a cross sectional approach, and a simple radom sampling technique. The sample was obtained as many as 164 respondents. Then the data were analyzed using spearman rank correlation with a significance level of $5 \%$.

Results: Most of the respondents have good knowledge (67.1\%), as well as behavior, the majority of respondents have safe driving behavior $(82.9 \%)$. The results of the spearman rank correlation analysis showed a $p$-value of 0.120 or greater than a significance of $5 \%$ ( $p>0.05$ ).

Conclusion: There is no significant relationship between knowledge and safety riding behavior.

\section{Keywords: Knowledge; Safety riding behavior; High school students}

Pendahuluan: Kalangan usia muda merupakan yang paling banyak terlibat kasus kecelakaan lalu lintas di Indonesia, diakibatkan gaya berkendara yang beresiko. Siswa SMA termasuk salah satu kelompok usia muda dengan usia rata-rata 15-18 tahun. Untuk menjamin keselamatan lalu lintas, dibentuk program safety riding yang mencakup perilaku disiplin dalam aturan dan tatacara berkendara. Perilaku sendiri dipengaruhi faktor pembentuk salah satunya pengetahuan. Pengetahuan sebagai ransangan atau stimulus dan menjadi dasar dalam bertindak. Tujuan: penelitian ini ingin mencari hubungan pengetahuan dengan perilaku safety riding pada siswa SMA.

Metode: Penelitian ini menggunakan metode observasional analitik dengan pendekatan cross sectional, dan teknik sampling simple radom sampling. Sampel diperoleh sebanyak 164 responden. Kemudian data dianalisis menggunakan korelasi spearman rank dengan tingkat kemaknaan $5 \%$.

Hasil: Sebagian besar responden memiliki pengetahuan dengan kategori baik $(67,1 \%)$, begitupun dengan perilaku, mayoritas responden memiliki perilaku berkendara aman $(82,9 \%)$. Hasil analisis korelasi spearman rank didapatkan $p$-value 0,120 atau lebih besar dari kemaknaan $5 \%(p>0,05)$.

Simpulan: Tidak terdapat hubungan signifikan antara pengetahuan dengan perilaku safety riding.

\section{Kata Kunci : Pengetahuan, Perilaku Safety Riding, Siswa SMA}

\section{PENDAHULUAN}

Kecelakaan lalu lintas merupakan salah satu penyebab kematian terbanyak didunia. Menurut Organisasi Kesehatan Dunia, kecelakaan lalu lintas mengakibatkan 1,24 juta orang meninggal per tahun dengan prevalensi $90 \%$ dari negara berpenghasilan menengah kebawah. Kalangan usia muda merupakan yang paling sering terlibat kecelakaan hingga menjadi korban, $60 \%$ kasus kecelakaan lalu lintas terjadi pada usia 15-29 tahun, sedangkan di Indonesia lebih tinggi pada usia 16-30 tahun (Johan, 2013; World Health Organization, 2013).

Kecelakaan lalu lintas pada dasarnya dipengaruhi faktor manusia, kendaraan, sarana, prasaran dan lingkungan. Faktor manusia yang paling berpengaruh terhadap kejadian kecelakaan karena menjadi unsur utama pergerakan lalu lintas. Rendahnya perilaku berkendara yang disiplin atau unsafe condition menjadi faktor pendorong terjadi kecelakaan lalu lintas (Ningsih \& Krishanandini 2019). Pada kalangan usia muda 
sering terlibat kecelakaan yaitu kebiasaan berkendara yang mereka lakukan, kebiasaan berkendara remaja cenderung beresiko, membahayakan diri sendiri maupun orang lain (Deery \& Flides, 1999; Handayani, Ophelia \& Hartono, 2017). Diketahui dari penelitian pada pelajar SMA Dua Mei Ciputat Timur sebanyak 79 siswa $(56,4 \%)$ memiliki perilaku berkendara yang buruk dan sisanya yang lebih rendah 61 siswa $(43,6)$ dengan perilaku kategori baik (Permatasari, 2018).

Menurut Undang-Undang Tentang Lalu Lintas Dan Angkutan Jalan, setiap pengguna jalan wajib berperilaku tertib, aman dan menjaga keamanan dan keselamatan lalu lintas. Safety riding merupakan program dalam rangka meningkatkan keselamatan dan meminimalkan angka kecelakaan lalu lintas. Adapun Safety riding meliputi kelengkapan STNK dan kepemilikan SIM, pemeriksaan kendaraan sebelum berkendara, penggunaan alat pelindung, mematuhi rambu perintah dan larangan, penggunaan lampu sein, penggunaan lampu utama, menggunakan jalur dan lajur dengan benar, mengatur jarak kendaraan, mengendara dengan wajar dan berkonsentrasi, mengatur kecepatan, membawa penumpang dengan kendaraan roda dua tidak lebih dari 1 orang (Departemen Perhubungan Republik Indonesia, 2009).

Namun dalam pelaksanannya tidak semua orang taat mempraktekkan safety riding, terlebih di daerah dengan tingkat kesadaran yang rendah. Tolitoli merupakan kota kecil dibagian Sulawesi Tengah, akibat tingkat kesadaran masyarakat dalam tertib berlalu lintas masih rendah sehingga pada tahun 2017 korban Kecelakaan Lalulintas (Lakalantas) meninggal mencapai 32 orang dibandingkan 25 Orang di tahun 2016 (Haruna, 2017). Perilaku berkendara dipengaruhi pemahaman dan pengetahuan berlalulintas yang aman dan tertib (Ningsih \& Krishanandini, 2019). Pengetahuan dapat diartikan stimulus atau rangsangan untuk terbentuknya sikap atau tindakan seseorang (Kholid, 2015; Pramono, Subekti, \& Atmoko, 2018). Pengetahuan atau kognitif merupakan bagian penting untuk terbentuknya perilaku seseorang, selain itu dapat menjadi dasar dalam berperilaku dan bertindak (Muryatma, 2018).

Dari studi pendahuluan yang dilakukan pada 30 siswa SMA Negeri 3 Tolitoli yang dilakukan secara online menggunakan format kuesioner (pada waktu pandemi Covid-19). Perilaku siswa mengenai safety riding teridentifikasi sebanyak 17 siswa diantaranya $(67,7 \%)$ kadang tidak menggunakan helm dan 6 siswa (20\%) sering tidak menggunakannya. Adapun penggunaan handPhone saat berkendara 13 siswa (43,3\%) menyatakan kadang melakukannya. Mendahului dari arah kiri 5 siswa $(16,7 \%)$ sering dan 10 siswa $(33,3 \%)$ kadang-kadang. Membawa penumpang lebih dari 1 orang dengan motor diketahui 21 siswa (70\%) pernah melakukan. Sehingga dapat dikatakan masih banyak siswa yang tidak menerapkan perilaku safety riding saat berkendara. Kemudian memperhatikan kondisi lalu lintas di sekitar sekolah yang sering dilalui kendaraan besar seperti truk dan konteiner, diharapkan para siswa memiliki perhatian lebih untuk berhati-hati dan menjaga perilaku safety riding. Sehingga berdasarkan uraian diatas, peneliti tertarik untuk meneliti hubungan pengetahuan dengan perilaku safety riding pada siswa SMA Negeri 3 kota Tolitoli.

\section{METODE PENELITIAN}

Penelitian ini merupakan penelitian kuantitatif, menggunakan desain observasional analitik dengan pendekatan cross sectional. Adapun tempat dan waktu penelitian dilakukan di SMA Negeri 3 Tolitoli pada bulan Juli - Agustus 2020. Populasi dalam penelitian ini adalah siswa kelas 2 dan 3 yang mampu mengendarai sepeda motor, menggunakan Simple Random Sampling dan didapatkan jumlah sampel sebanyak 164 siswa.

Pengumpulan data dilakukan menggunakan kuesioner yang merujuk pada Undang-Undang Nomor 22 tahun 2009 tentang Lalu Lintas dan Angkutan Jalan serta Buku Petunjuk Tata Cara Bersepeda Motor Indonesia oleh Dirjen Perhubungan Darat tahun 2008 dan dilaksanakan secara online melalui googleform. Adapun jumlah pertanyaan untuk kuesioner pengetahuan berjumlah 17 pertanyaan dengan kategori skor yaitu dikategorikan berpengetahuan baik apabila skor 6-17; dan berpengetahuan kategori buruk apabila dalam rentang 0-5. Kuesioner tersebut telah diuji untuk hasil uji validitas dilakukan pada 30 orang dengan $r$ tabel $(0,361)$, dan untuk uji reabilitas nilai $r$ hitung kuesioner pengetahuan adalah 0,966 yang mana $>0,6$ sehingga dikatakan reliabel.

Kuesioner perilaku safety riding berjumlah 19 pertanyaan, dan dikatakan aman apabila skor $\geq 48$ dan tidak aman apabila < 48. Hasil uji validitas pada 30 orang didapatkan $r$ tabel $(0,361)$, dan 
reabilitas nilai $r$ hitung untuk kuesioner perilaku 0,574 . Nilai tersebut lebih besar dari $r$ tabel $(0,361)$ sehingga kuesioner dikatakan reliabel. Layak etik didapatkan dari komisi etik penelitian kesehatan Universitas Muhammadiyah Malang, Nomer E.5.a/117/KEPK-UMM/IV/2020.
Penelitian tidak dapat dilakukan secara tatap muka diakibatkan pandemi Covid-19 yang sedang terjadi. Data yang terkumpul dianalisis secara univariat dan bivariat menggunakan uji statistik Spearman Rank dengan $a=0,05$, untuk mengetahui hubungan antar variabel.

\section{HASIL}

Table 1 Gambaran Karakteristik Responden N=164

\begin{tabular}{|c|c|c|c|}
\hline \multicolumn{2}{|c|}{ Karakteristik Responden } & Frekuensi (f) & Presentasi (\%) \\
\hline \multicolumn{2}{|l|}{$\begin{array}{l}\text { Umur (Tahun) } \\
\text { (Rentang:15-18) } \\
(M \pm S D)(16.37 \pm 0.73)\end{array}$} & 164 & 100 \\
\hline Jenis Kelamin & $\begin{array}{l}\text { Laki-Laki } \\
\text { Perempuan }\end{array}$ & $\begin{array}{l}73 \\
91\end{array}$ & $\begin{array}{l}44.5 \\
55.5\end{array}$ \\
\hline \multirow[t]{2}{*}{ Kelas } & XI & 83 & 50.6 \\
\hline & XII & 81 & 49.4 \\
\hline Kepemilikkan SIM & $\begin{array}{l}\text { Ada } \\
\text { Tidak Ada }\end{array}$ & $\begin{array}{c}8 \\
156\end{array}$ & $\begin{array}{c}4.9 \\
95.1\end{array}$ \\
\hline \multirow{2}{*}{$\begin{array}{l}\text { Pengalaman } \\
\text { Kecelakaan }\end{array}$} & Ada & 100 & 61.0 \\
\hline & Tidak Ada & 64 & 39,1 \\
\hline \multirow[t]{2}{*}{ Masa Berkendara } & Baru (<3 Tahun) & 58 & 35.4 \\
\hline & Lama ( $\geq 3$ Tahun) & 106 & 64.6 \\
\hline Pengetahuan & \begin{tabular}{l}
\multicolumn{1}{c}{ Hasil Pen } \\
Kategori Baik \\
Kategori Buruk
\end{tabular} & $\begin{array}{l}110 \\
54\end{array}$ & $\begin{array}{l}67,1 \\
32.9\end{array}$ \\
\hline Perilaku & $\begin{array}{l}\text { Aman } \\
\text { Tidak Aman }\end{array}$ & $\begin{array}{l}143 \\
21\end{array}$ & $\begin{array}{l}87.2 \\
12.8\end{array}$ \\
\hline
\end{tabular}

Berdasarkan Tabel 1 diketahui dari seluruh responden yang berjumlah 164 lebih banyak berjenis kelamin perempuan $(55,5 \%)$, berumur rata-rata mean 16.37 tahun dengan standar deviasi $\mathbf{\pm 0 . 7 3}$ dengan rentang usia 15-18 tahun dan berada pada tingkat kelas XI $(50,6 \%)$. Status kepemilikkan SIM hanya sebagian kecil yang memiliki yaitu 8 responden $(4,9 \%)$, sedangkan untuk pengalaman kecelakaan sebagian besar responden pernah mengalami kecelakaan yaitu sebanyak 100 responden (61\%) dan untuk masa berkendara lebih banyak responden yang diatas 3 tahun atau termasuk kategori lama yaitu sebanyak 106 responden (64,6\%), adapun hasil penelitian pengetahuan safety riding yang termasuk dalam kategori baik lebiih banyak dibanding kategori cukup yaitu 110 responden $(67,1 \%)$, dan hasil penelitian perilaku safety riding didapatkan sebagian besar responden memiliki perilaku berkendara yang aman atau safety riding, yaitu sebanyak 143 responden $(87,2 \%)$. 
Holistik Jurnal Kesehatan, Volume 14, No.4, Desember 2020: 564-572

Pengetahuan dan Perilaku Safety Riding Siswa SMA

Tabel 2. Hubungan Pengetahuan dengan Perilaku Safety Riding

\begin{tabular}{|c|c|c|c|c|c|c|c|}
\hline \multirow[t]{2}{*}{ Pengetahuan } & \multicolumn{4}{|c|}{$\begin{array}{c}\text { Perilaku Safety Riding } \\
\text { Kategori Aman Kategori Tidak Aman }\end{array}$} & \multicolumn{2}{|c|}{ Total } & \multirow[t]{2}{*}{$p$-value } \\
\hline & $n$ & $\%$ & $\mathrm{n}$ & $\%$ & $\mathbf{N}$ & $\%$ & \\
\hline Kategori Baik & 100 & 60.9 & 10 & 6.2 & 110 & 67.1 & \\
\hline Kategori Buruk & 43 & 26.2 & 11 & 6.7 & 54 & 32.9 & 0.120 \\
\hline
\end{tabular}

Berdasarkan tabel 2 diketahui hasil penelitian sebagai berikut, siswa SMA Negeri 3 Tolitoli dengan keseluruhan jumlah responden sebanyak 164 responden, adapun yang termasuk memiliki pengetahuan baik dengan perilaku berkendara yang aman sebanyak 100 responden $(60.9 \%)$ sedangkan yang tidak berperilaku aman 10 responden $(6.2 \%)$. Pada kategori pengetahuan cukup dengan perilaku berkendara aman terdapat 43 responden $(26.2 \%)$ sedangkan yang melakukan perilaku tidak aman sebanyak 11 responden $(6.7 \%)=$ Hasil ini menunjukkan perbandingan responden dengan perilaku berkendara aman lebih besar dibanding responden dengan perilaku yang tidak aman sehingga dapat dikatakan walaupun memiliki pengetahuan cukup namun ada jyang memiliki perilaku berkendara yang aman. Adapun hasil analisis statistik dengan uji Spearman Rank didaptkan $p$-value $0,120 \quad(p>0,05)$. Maka disimpulkan tidak ada hubungan signifikan antara pengetahuan dengan perilaku safety riding pada siswa SMA Negeri 3 Tolitoli.

\section{PEMBAHASAN}

\section{Kepemilikkan Surat Izin Mengemudi (SIM)}

Menurut Buku Petunjuk Tata cara Bersepeda Aman Indonesia oleh Ditjen Perhubungan Darat (2009), untuk dapat menggunakan kendaraan bermotor harus mempunyai SIM yang sah sesuai kendaraan yang digunakan. Untuk mengendarai sepeda motor diperlukan SIM C. Surat izin mengemudi penting dimiliki semua pengendara sebagai lisensi telah diizinkan membawa kendaraan dan telah dinyatakan lolos tes berkendara oleh pihak kepolisian dan salah satu faktor keselamatan adalah memiliki SIM (Muryatma, 2018).

Hasil penelitian diketahui dari 164 responden hanya 8 responden yang memiliki SIM dan 156 diantaranya tidak. Berdasarkan analisis karakteristik responden $59,2 \%$ berumur $<17$ tahun, yang mana usia minimal untuk mendapatkan SIM adalah 17 tahun. Sehingga sebagian besar responden belum memenuhi syarat memperoleh surat izin mengemudi dan secara hukum belum memenuhi syarat mengendarai sepeda motor.

\section{Pengalaman Kecelakaan}

Hasil penelitian didapatkan 100 responden $(61 \%)$ memiliki pengalaman kecelakaan lalu lintas atau pernah mengalami kecelakaan. Karakteristik responden yang merupakan remaja, sebagaimana menurut beberapa pendapat bahwa remaja atau usia muda lebih besar mengalami kecelakaan akibat kebiasaan berkendara yang cenderung beresiko, membahayakan diri sendiri maupun orang lain, seperti kurang memperhatikan rambu dan marka lalu lintas, tetap memacu kendaraan saat lampu telah kuning, kecepatan tinggi lebih dari $60 \mathrm{~km} / \mathrm{jam}$, menggunakan alat komunikasi saat berkendara baik menelpon, membalas pesan maupun mendengarkan musik dan merokok sambil berkendara (Deery \& Flides, 1999; Handayani, Ophelia \& Hartono, 2017).

Adapun Pengalaman merupakan salah satu faktor dalam perubahan perilaku maupun peningkatan pengetahuan. Pengalaman kesalahan dalam berkendara hingga mengakibatkan kecelakaan, dapat meningkatkan kemampuan dan pengetahuan menilai resiko.

Pengendara yang menggunakan kendaraan dengan tidak aman cenderung menurun seiring bertambahnya pengalaman. Pengalaman adalah suatu memori yang menjadi pembelajaran dan menambah pengetahuan yang kapanpun bisa diterapkan sesuai kondisi (Nurtanti, 2002; Nasrullah \& Suwandi, 2014)

Berdasarkan hasil penelitian sebelumnya menyatakan terdapat hubungan pengalaman dengan perilaku safety riding pada responden mahasiswa program studi kesehatan masyarakat Universitas Muhammadiyah Surakarta dengan $p$ value 0,004 (Aeni, 2016). 


\section{Masa Berkendara}

Masa berkendara adalah masa yang terhitung mulai pertama kali responden mampu menggunakan kendaraan sampai pada saat dilakukan penelitian. Lama masa berkendara dibutuhkan untuk menambah pengalaman dan keahlian berkendara, sesuai waktu dan frekuensi berkendara. Semakin lama berkendara diharapkan dapat menambah keterampilan dan kesiapsiagaan menjaga keselamatan berlalu lintas (Muryatma, 2018).

Berdasarkan hasil penelitian, rata-rata masa berkendara responden 3,4 tahun dengan masa berkendara minumun 1 tahun dan maksimal 8 tahun. Adapun yang termasuk kategori baru adalah $<3$ tahun dan kategori lama $\geq 3$ tahun. Hasil yang didapatkan $64,4 \%$ atau 106 dari 164 responden termasuk kategori lama. Terkait hubungan dengan perilaku safety riding, Hasil penelitian di kota Medan pada pengendara Go-Jek menjelaskan terdapat hubungan antara lama berkendara dengan perilaku safety riding dengan nilai $p$-value $0,000(p<0,05)$. (Manurung, Sitorus \& Rinaldi 2019).

\section{Pengetahuan Safety Riding}

Pengetahuan adalah suatu hasil dari mengetahui yang berawal dari proses penginderaan, yakni meliputi penglihatan, pendengaran, penciuman, perasa, dan perabaan. Sebagian besar manusia memperoleh pengetahuan melalui kemampuannya melihat dan mendengar (Wawan \& Dewi, 2016). Adapun pengetahuan safety riding merupakan bekal yang harus dimiliki sebelum mengendarai kendaraan yang menekankan pada penguasaan kemampuan, keterampilan pengendalian, mental serta attitude yang mana akan semakin baik seiring dengan lama masa berkendara dan pengalaman (Hidayat \& Lakoro, 2012). Pengetahuan safety riding akan membiasakan seseorang untuk lebih hati-hati dan sadar untuk menggunakan kendaraan secara aman (Sibyan, 2018).

Hasil penelitian menunjukkan siswa SMA Negeri 3 Tolitoli sebagian besar memiliki pengetahuan safety riding kategori baik yaitu 110 siswa $(67,1 \%)$. Artinya banyak dari responden yang mengetahui tentang berkendara secara aman. Dari hasil analisis jawaban, sebagian besar poin pertanyaan dijawab benar oleh responden, terhitung 15 pertanyaan yang $>80 \%$ dijawab dengan benar. Sedangkan 2 pertanyaan terjawab
$78,7 \%$ dan $40,8 \%$. Beberapa pertanyaan yang dijawab benar merupakan pengetahuan saat melakukan kegiatan berkendara seperti jalur yang tepat saat berkendara, keadaan saat berkendara dan aturan-aturan saat berkendara, sehingga dapat disimpulkan sebagian besar responden mengetahui tata cara berkendara dengan aman.

\section{Perilaku Safety Riding}

Perilaku ialah respon individu dalam menanggapi stimulus, atau dapat dikatakan suatu tindakan yang mampu diamati dan memiliki frekuensi spesifik, durasi, dan tujuan yaitu baik yang disadari maupun tidak. Pada manusia diartikan perilaku adalah berbagai aktivitas yang dilakukan baik yang dapat diamati maupun yang tidak dapat diamati oleh pihak luar (Wawan \& Dewi, 2016). Perilaku safety riding merupakan perilaku mengemudi yang aman dan dapat membantu untuk menghindari terjadinya kecelakaan lalu lintas. Perilaku safety riding meliputi 3 hal yaitu sebelum, saat dan setelah berkendara yang diawali dengan kesadaran untuk mengutamakan keselamatan, baik bagi diri sendiri maupun orang lain (Ariwibowo, 2013).

Hasil penelitian ini diketahui perilaku safety riding pada siswa SMA Negeri 3 Tolitoli sebagian besar dalam kategori aman yaitu 143 siswa $(87,2 \%)$. Dari analisis jawaban terdapat 5 pertanyaan yang $>50 \%$ dijawab selalu, dengan presentasi tertinggi $76,8 \%$ dan terendah $59,2 \%$. Sedangkan yang menjawab tidak pernah pada seluruh pertanyaan hanya sebagian kecil responden dengan presentase $<10 \%$, adapun presentase tertinggi adalah $21,9 \%$ dan terendah $0 \%$. Sehingga skor yang didapatkan cenderung tinggi. Beberapa pertanyaan yang sebagian besar dijawab dengan selalu yaitu memanaskan kendaraan sebelum berkendara, mematuhi lampu lalu lintas, menggunakan lampu sein untuk (berbelok, berpindah jalur, atau menyalip) dan menyalakan lampu utama dimalam hari. Dan pertanyaan dengan jawaban tidak pernah pada presentase tertinggi adalah Seberapa seringkah Anda menggunakan sarung tangan saat berkendara.

\section{Hubungan Pengetahuan dengan Perilaku Safety Riding}

Pengetahuan atau kognitif merupakan faktor penting dalam pembentukan perilaku seseorang, perilaku yang didasari pengetahuan akan lebih 
terarah, bermakna dan konsisten untuk dilakukan (Wawan \& Dewi, 2016). Pengetahuan dapat diartikan stimulus atau rangsangan untuk terbentuknya sikap atau tindakan seseorang. Sama halnya dengan perilaku berkendara, jika dipengaruhi pemahaman dan pengetahuan berlulintas yang aman dan tertib akan menghasilkan perilaku yang baik dalam berkendara (Kholid, 2015; Pramono et al, 2018).

Adapun penelitian ini mendapatkan hasil, uji statistik menggunakan Spearman Rank didapatkan $p$-value $0.120(p>0.05)$ yang berarti tidak terdapat hubungan signifikan antara pengetahuan dengan perilaku safety riding. Hasil penelitian ini sama dengan penelitian yang dilakukan pada siswa SMK PGRI 4 Surabaya, yang menggunakan uji statistik Chi-Square, mendapatkan $p$-value $1.921(p>0,05)$, sehingga disimpulkan tidak terdapat hubungan signifikan antara pengetahuan dan perilaku safety riding (Muryatma, 2018).

Adapun hasil analisis, jumlah responden dengan pengetahuan baik dan perilaku berkendara aman terdapat 100 responden (60.9\%) sedangkan yang tidak berperilaku aman 10 orang (6.2\%). Pada kategori pengetahuan cukup dengan perilaku berkendara yang aman, terdapat 43 orang $(26.2 \%)$ sedangkan yang melakukan perilaku tidak aman sebanyak 11 orang $(6.7 \%)$ nilai ini lebih rendah dibandingkan yang memiliki pengetahuan cukup namun memiliki perilaku berkendara yang aman. Hasil ini menunjukkan walaupun sebagian besar responden memiliki pengetahuan cukup namun memiliki perilaku berkendara yang aman.

Berdasarkan distribusi karakteristik responden, jumlah responden penelitian ini lebih banyak terdiri dari perempuan yaitu 91 (55.5\%) dari 164 responden. Sebagaimana menurut beberapa pendapat bahwa perempuan cenderung lebih memperhatikan aturan berlalu lintas dan berhatihati dalam berkendara (Reason, 1990; Chang \& Yeh, 2007; Shi, Bai, Ying \& Atchley, 2010; Haryanto, 2016)

Perempuan memiliki persepsi terhadap resiko yang lebih baik dibandingkan laki-laki, sehingga perempuan tidak banyak melakukan manuver agresif saat bekendara.

Dalam studinya pengendara usia muda khususnya laki-laki cenderung lebih memiliki evaluasi negatif terhadap aturan lalu lintas dibanding perempuan (Yagil, 1998; Haryanto, 2016). Keberadaan evaluasi positif terhadap aturan akan mempengaruhi perilaku berkendara. Dimana saat seseorang mampu melihat dan mengetahui manfaat menaati aturan yang dapat mencegah dirinya dari kecelakaan maupun menjadi korban, hal itu membuat seseorang lebih disiplin menaati aturan saat berkendara.

Selain itu, dari faktor-faktor yang mempengaruhi pengetahuan bukan merupakan satu-satunya faktor pembentuk perilaku, menurut terdapat 2 faktor utama yang mempengaruhi terbentuknya perilaku yaitu faktor dari diri sendiri dan faktor dari luar (Green, \& Kreuter, 1991). Adapun yang berasal dari diri sendiri yaitu pengetahuan, persepsi, kepercayaan, pengalaman dan nilai-nilai. Peningkatan pengetahuan tidak selalu menyebabkan perubahan perilaku dan belum tentu menjadi satu-satunya faktor yang cukup untuk merubah perilaku seseorang, tetapi pengetahuan sangat penting diberikan sebelum individu melakukan suatu tindakan (Green, \& Kreuter, 1991; Puteri, Nisa, Pahlawan, \& Tambusai, 2020). Seperti hasil penelitian sebelumnya yang menyatakan pengetahuan berhubungan dengan perilaku pencegahan kecelakaan sepeda motor (Notosiswoyo, 2014)

Adapun faktor lain yang dapat menyebabkan perubahan perilaku adalah pengalaman. Perubahan perilaku seseorang dapat diketahui dari pengalaman. Pengalaman dapat diartikan suatu proses pembentukkan keterampilan yang dipengaruhi sebagian besar praktek yang dilakukan (Notoatmodjo, 2007; Aeni, 2016). Seperti halnya banyaknya pengalaman berkendara akan melatih keterampilan dalam berkendara, proporsi pengendara yang melakukan perilaku tidak aman cenderung menurun seiring bertambahnya pengalaman (Nurtanti, 2002; Aeni, 2016). Dalam penelitian ini mayoritas responden mempunyai pengalaman kecelakaan yaitu 100 responden (61\%). Pengalaman kecelakaan dapat mengajarkan pengendara menilai resiko, dikarenakan sudah pernah berada diposisi dan situasi yang demikian sehingga mampu memperkirakan kemungkinan terburuk yang menyebabkan kecelakaan, dan secara tidak langsung mempengaruhi cara berkendara dengan lebih berhati-hati dan memawas diri.

Selain itu faktor lain yang mungkin mempengaruhi adalah masa berkendara. Berdasarkan hasil penelitian di kota Medan menunjukkan terdapat hubungan signifikan antara masa berkendara dengan perilaku safety riding 
pada pengendara GO-Jek dengan $p$-value $\quad 0,000$ $(<0,05)$ (Manurung, Sitorus \& Rinaldi, 2019).

Berdasarkan hasil penelitian ini rata-rata masa berkendara adalah 3,4 tahun. Rata-rata masa berkendara digunakan sebagai parameter dengan $<3$ tahun sebagai kategori baru dan $\geq 3$ tahun kategori lama. Adapun hasil yang didapatkan $64,4 \%$ atau 106 responen memiliki masa berkendara $\geq 3$ tahun dan yang memiliki masa berkendara $<3$ tahun 58 reponden $(35,4 \%)$ dengan yang memiliki pengalaman kecelakaan sebanyak 100 responden (61\%).

Masa berkendara yang semakin lama akan memberikan banyak peristiwa dan pengalaman dibanding dengan masa berkendara yang terbilang baru. Pengendara dapat mengambil pelajaran seiringan lama dan banyaknya peristiwa yang dialami.

Hal tersebut sesuai dengan pendapat bahwa meningkatnya kecelakaaan lalu lintas yang melibatkan pengendara usia muda disebabkan sedikitnya pengalaman berkendara selain itu lebih sering dialami pengemudi baru dengan pengalaman berkendara kurang lebih satu tahun dibanding yang memiliki pengalaman lebih lama (Vandaele, 1983; Maharani, 2016).

\section{SIMPULAN}

Sebagian besar responden siswa SMA Negeri 3 Tolitoli memiliki pengetahuan safety riding yang kategori baik, dan juga memiliki perilaku berkendara yang aman atau safety riding. Namun dari hasil uji statistik tidak terdapat hubungan signifikan antara pengetahuan dengan perilaku safety riding, dan sesuai hasil penelitian hal itu dipengaruhi dari jumlah responden yang sebagian besar berjenis kelamin perempuan, sebagian besar memiliki pengalaman kecelakaan, hingga memiliki masa berkendara yang termasuk lama yaitu $\geq 3$ tahun.

\section{SARAN}

Berdasarkan hasil penelitian dan faktor karakteristik responden yang dapat mempengaruhi hasil penelitian, peneliti menyarakan untuk memperhatikan sebaran jenis kelamin responden terlebih untuk penelitian yang kemungkinan hasilnya sangat dipengaruhi dari karakteristik jenis kelamin seperti penelitian perilaku safety riding dan diharapkan akan ada penelitian korelasi maupun komparatif dengan topik jenis kelamin, pengalaman maupun masa berkendara yang hubungannya dengan perilaku safety riding.

\section{DAFTAR PUSTAKA}

Aeni, Q. (2016). Faktor Yang Berhubungan Dengan Perilaku Safety Riding Pada Mahasiswa Kesehatan Masyarakat Sebagai Pengendara Sepeda Motor. Skripsi Kesehatan Masyarakat, 1-14.

Ariwibowo, R. (2013). Hubungan Antara Umur, Tingkat Pendidikan, Pengetahuan, Sikap Terhadap Praktik Safety Riding Awareness Pada Pengendara Ojek Sepeda Motor Di Kecamatan Banyumanik. Jurnal Kesehatan Masyarakat, 2(1), 1-8. https://doi.org/10.1017/CBO9781107415324.00 4

Chang, H. L., \& Yeh, T. H. (2007). Motorcyclist accident involvement by age, gender, and risky behaviors in Taipei, Taiwan. Transportation research part $F$ : traffic psychology and behaviour, 10(2), 109-122.

Deery, H. A., \& Fildes, B. N. (1999). Young novice driver subtypes: Relationship to high-risk behavior, traffic accident record, and simulator driving performance. Human factors, 41(4), 628-643.

Departemen Perhubungan Republik Indonesia Ditjen Perhubungan Darat. (2009). Buku petunjuk tata cara bersepeda motor di Indonesia, $\quad$ 1-69. http://hubdat.dephub.go.id/artikel-ditjen-ktd/28tata-cara-bersepeda-motor-diindonesia?showall $=1$. Diakses pada tanggal 21 Desember 2019.

Departemen Perhubungan Republik Indonesia, (2009). Undang-Undang Republik Indonesia Nomor 22 Tahun 2009 Tentang Lalu Lintas Dan Angkutan Jalan. http://jdih.dephub.go.id/assets/uudocs/uu/uu_n 
0.22_tahun_2009.pdf. Diakses pada tanggal 21 Desember 2019

Green, L. W., \& Kreuter, M. W. (1991). Health promotion planning: an educational and environmental approach.

Handayani, D., Ophelia, R. O., \& Hartono, W. (2017). Pengaruh pelanggaran lalu lintas terhadap potensi kecelakaan pada remaja pengendara sepeda motor. E-Jurnal Matrks Teknik Sipil, (September), 838-843.

Haruna, M. (2017). Korban Lakalantas di Tolitoli Meningkat. Retrieved September 5, 2020, from https://www.sultengnews.com/tahun-2017korban-lakalantas-di-tolitoli-meningkat/

Haryanto, H.C. (2016). Keselamatan Dalam Berkendara: Kajian Terkait Dengan Usia Dan Jenis Kelamin Pada Pengendara. Inquiry Jurnal IImiah Psikologi, 7(2), 231153.

Hidayat, R. \& Lakoro, R. (2012). Perancangan Buku Visual Safety Riding untuk Remaja Usia 16 - 18 Tahun Sebagai Panduan Keselamatan Oleh Honda. Jurnal Sains dan Seni ITS 1(1), 11-16.

Johan, H. (2013) Polantas dalam Angka Tahun 2013. https://adoc.pub/polantas-dalam-angkatahun-2013.html (diakses tanggal 16 Desember 2019)

Kholid, A. (2015). Promosi kesehatan dengan pendekatan teori perilaku, media, dan aplikasinya. Jakarta: Rajawali Pers.

Maharani, D. (2016). Faktor-Faktor Yang Berhubungan Dengan Perilaku Remaja Berkendara Sepeda Motor Di Sepanjang Ruas Jalan Matraman-Rawamangun, Jakarta Timur Tahun 2016. Journal of Chemical Information and Modeling (Vol. 53). https://doi.org/10.1017/CBO9781107415324.00 $\underline{4}$

Indri Wahyuningsih*, Syahra Ramdana

Fakultas Ilmu Kesehatan Universitas Muhammadiyah Malang. *Email: indri@umm.ac.id
Manurung, J., Sitorus, M. E., \& Rinaldi, R. (2019). Faktor-Faktor yang Berhubungan dengan Perilaku Safety Riding Pengemudi Ojek Online (Go-Jek) di Kota Medan Sumatera Utara. Journal of Health Science and Physiotherapy, 1(2), 91-99.

Muryatma, N. M. (2018). Hubungan Antara Faktor Keselamatan Berkendara Dengan Perilaku Keselamatan Berkendara. Jurnal PROMKES, $5(2)$, 155. https://doi.org/10.20473/jpk.v5.i2.2017.155-166

Ningsih, E.D., \& Krishanandini N.A.R. (2019). Pengaruh Tingkat Pengetahuan Tentang Berlalu Lintas, Tingkat Pendidikan Dan Usia Terhadap Motivasi Kepatuhan Dalam Berlalu Lintas Pada Warga, Kosala: Jurnal IImu Kesehatan 7(2), 55-64.

Notosiswoyo, M. (2014). Pengetahuan, Sikap Dan Perilaku Siswa Slta Dalam Pencegahan Kecelakaan Sepeda Motor Di Kota Bekasi. Jurnal Ekologi Kesehatan, 13(1), 1-9.

Nurtanti, D. (2002). Gambaran Perilaku Pengendara Sepeda Motor di Jalan Arteri Margonda Depok Terhadap Kecelakaan Lalu Lintas Tahun 2012. Skripsi. FKM Universitas Indonesia.

Permatasari, A. (2018). Gambaran Perilaku Keselamatan Berkendara Pada Pelajar SMA Dua Mei Ciputat Timur Tahun 2017.

Pramono, T. D., Subekti, A. T., \& Atmoko, D. (2018). Hubungan pengetahuan dan sikap dengan praktik keselamatan berkendara sepeda motor pada siswa smk semesta bumiayu. Jurnal IImu Kesehatan (JIK) Bhamada, 9(1), 8-8. 
Puteri, A. D., Nisa, A. M., Pahlawan, U., \& Tambusai, T. (2020). Faktor-Faktor Yang Berhubungan Dengan Perilaku Safety Driving Pada Supir Travel Di Pt . Libra Wisata Transport, 4(April), 1-10.

Reason, J. (1990). Human error. Cambridge university press.

Shi, J., Bai, Y., Ying, X., \& Atchley, P. (2010). Aberrant driving behaviors: A study of drivers in Beijing. Accident Analysis \& Prevention, 42(4), 1031-1040.

Sibyan, A. (2018). Hubungan Antara Masa Berkendara Dan Pengetahuan Dengan Perilaku Safety Riding (Studi Kasus Pelajar Sma Negeri 5 Kota Tegal), 19-20.
Vandaele, W. (1983). Applied time series and BoxJenkins models (No. 04; HB3730, V3.).

Wawan, A. \& Dewi, M. (2016). Teori \& Pengukuran Pengetahuan, Sikap, Dan Perilaku Manusia. Yogyakarta: Nuha Medika

World Health Organization, (2013). Global Status Report on Road Safety 2013. Retrieved from https://www.who.int/violence_injury_prevention/ road safety status/2013/en/ 